\title{
Health Risk of Polonium 210 Ingestion via Drinking Water: An Experience of Malaysia
}

\author{
Minhaz Farid Ahmed ${ }^{1}$ (D), Lubna Alam ${ }^{1, *}$, Che Abd Rahim Mohamed ${ }^{2}$, Mazlin Bin Mokhtar ${ }^{1}$ \\ and Goh Choo Ta ${ }^{1}$ \\ 1 Institute for Environment and Development (LESTARI), Universiti Kebangsaan Malaysia (UKM), \\ UKM Bangi 43600, Selangor, Malaysia; minhazhmd@yahoo.com (M.F.A.); mazlin@ukm.edu.my (M.B.M.); \\ gohchoota@ukm.edu.my (G.C.T.) \\ 2 School of Environmental and Natural Resource Sciences, Universiti Kebangsaan Malaysia (UKM), \\ UKM Bangi 43600, Selangor, Malaysia; carmohd@ukm.edu.my \\ * Correspondence: lubna762120@gmail.com or lubna@ukm.edu.my; Tel.: +60-389-217-656
}

Received: 10 July 2018; Accepted: 30 August 2018; Published: 20 September 2018

\begin{abstract}
The presence of toxic polonium-210 (Po-210) in the environment is due to the decay of primordial uranium-238. Meanwhile, several studies have reported elevated Po-210 radioactivity in the rivers around the world due to both natural and anthropogenic factors. However, the primary source of Po-210 in Langat River, Malaysia might be the natural weathering of granite rock along with mining, agriculture and industrial activities. Hence, this is the first study to determine the Po-210 activity in the drinking water supply chain in the Langat River Basin to simultaneously predict the human health risks of Po-210 ingestion. Therefore, water samples were collected in 2015-2016 from the four stages of the water supply chain to analyze by Alpha Spectrometry. Determined Po-210 activity, along with the influence of environmental parameters such as time-series rainfall, flood incidents and water flow data (2005-2015), was well within the maximum limit for drinking water quality standard proposed by the Ministry of Health Malaysia and World Health Organization. Moreover, the annual effective dose of Po-210 ingestion via drinking water supply chain indicates an acceptable carcinogenic risk for the populations in the Langat Basin at 95\% confidence level; however, the estimated annual effective dose at the basin is higher than in many countries. Although several studies assume the carcinogenic risk of Po-210 ingestion to humans for a long time even at low activity, however, there is no significant causal study which links Po-210 ingestion via drinking water and cancer risk of the human. Since the conventional coagulation method is unable to remove Po-210 entirely from the treated water, introducing a two-layer water filtration system at the basin can be useful to achieve SDG target 6.1 of achieving safe drinking water supplies well before 2030, which might also be significant for other countries.
\end{abstract}

Keywords: drinking water; radioactivity; annual effective dose; carcinogenic

\section{Introduction}

Po-210, a decay element of U-238, is a naturally occurring radionuclide mostly found in water, soil and food. The significant sources of terrestrial radiation are primordial radionuclides, namely U-238, Th-232, and K-40, which are dispersed around the Earth's crust and widely reported in Peninsular Malaysia [1]. In the Langat River, Po-210 is mainly due the natural weathering of the minerals, uraninite $\mathrm{UO}_{2}$ (pitchblend), carnotite, and autunite of the acid intrusive granitic rock [2-4]. Therefore, human beings are at risk of ingestion of Po-210 through drinking water and exposure to annual effective doses for a long time. Moreover, Po-210 is considered as one of the primary sources of alpha exposure [5] to human beings through ingestion via drinking water [6-8]. Alam and Mohamed [5] also reported 
Po-210 is about 250,000 times more toxic than hydrogen cyanide; therefore, it could be carcinogenic if ingested through drinking water [9-13].

Natural sources contribute about $80 \%$ to the radionuclides generated in Malaysia, the other sources being anthropogenic ones such as industrial activities as well as mining of natural resources along with gas and petroleum exploration [14]. Many studies in Peninsular Malaysia have investigated the existence of radioactivity from Ra-226, Ra-228, Pb-210, Cs-137, Th-232, K-40 and Rn-222 in water bodies [15-18] and it was reported that about 80 to $87 \%$ of the human exposure to radioactivity in Peninsular Malaysia results mainly from natural sources such as primordial radionuclides, cosmogenic radionuclides, etc. $[14,16]$. The atmospheric source is also considered as one of the sources of Po-210 in water because of the decay of Rn-222 gas and the decay of naturally occurring U-238 [15,19].

Malaysia has seriously focused on industrial expansion to achieve developed country status by 2020 [20,21]. As a result, the rivers in Malaysia have been found to be severely contaminated with heavy metals [22] as well as radioactive elements $[17,23,24]$. Rapid mineralization of tin ore from the Main Range Granite is the prime source of the high radioactivity associated with soil in the western region of Peninsular Malaysia [2]. In Selangor state, the maximum activity of U-238, Ra-226, Th-232, and K-40 recorded in sediments from the tin recycling ponds are higher than the rest of Malaysia and is the world's highest natural activity [25]. The DOE [26] reported that the industrial sector and quarries are responsible for the source points of pollution in the Langat River, quantified at $8.14 \%$ and $0.24 \%$, respectively. Therefore, significant sources of primordial radionuclides in the Langat River Basin are sand and gravel extraction $56.21 \%$, and earth material extraction $28.10 \%$, along with granite quarries $13.73 \%$ [27].

In Malaysia, the naturally occurring radionuclides are usually generated from the mining and mineral processing industries. For instance, in Selangor, more than 30 illegal sand mining sites, mainly in the Hulu Selangor, Sepang, and Kuala Langat districts have been identified in the last 20 years, while the government has given permits to only 46 sites for sand mining in private lands [28]. In the Langat, Lui, and Semenyih River Sub-basins, the mining area is about 3.28, 10.55, and $4.63 \mathrm{~km}^{2}$, respectively, and the mining area trend is increasing [29]. However, the Malaysian government-based on the Atomic Energy Licensing (Radioactive Waste Management) Regulations 2011-allows industries to run if the generation of natural radionuclides remains below $1 \mathrm{~Bq} / \mathrm{g}[30,31]$. Similarly, the Ministry of Health Malaysia recommends that the gross alpha $(\alpha)$ and gross beta $(\beta)$ levels of both in the river and drinking water should not exceed $0.1 \mathrm{~Bq} / \mathrm{L}$ and $1.0 \mathrm{~Bq} / \mathrm{L}$, respectively, as set by the National Standard for Drinking Water Quality [32].

Langat River in Selangor state is not only one of the primary local sources of drinking water [33,34], but rivers are in general the primary sources of drinking water in all Malaysia. Studies on natural radionuclides in the Langat River have reported that the radioactivity of some radionuclides in the river such as U-238 (3.85 Bq/L), Th-232 (1.14 Bq/L), K-40 (145.67 Bq/L) [23], and Ra-226 (0.26 Bq/L) [35] has exceeded the limit of both the gross alpha $0.1 \mathrm{~Bq} / \mathrm{L}$ and gross beta $1.0 \mathrm{~Bq} / \mathrm{L}$ emitters set by the Malaysian standard for raw water quality [32]. Similarly, are only a few studies on the radioactivity of radionuclides in the drinking water of Malaysia, which were reported safe through ingestion [36]. However, in some places of Malaysia the activity of Ra-226, i.e., $0.30 \mathrm{~Bq} / \mathrm{L}$ in drinking water was recorded above the standard set by the United States Environmental Protection Agency. Moreover, the range of annual effective doses from radionuclides in some places of Malaysia was determined to be $0.02 \mathrm{mSv} /$ year to $0.06 \mathrm{mSv} /$ year [19,37].

As there is no significant study on Po-210 in the drinking water supply chain of Malaysia, there is an urgency to study the Po-210 activity in drinking water because of its high radiotoxicity. Since the Langat River is situated on the acid intrusive granite rock belt that is the prime source of U-238 including Po-210, determining the Po-210 activity in the drinking water and its annual effective dose to humans through ingestion is very important concerning human health carcinogenicity risks. Therefore, this study investigated the Po-210 activity in the drinking water of Langat River Basin and the annual effective dose through ingestion via drinking water. 


\section{Materials and Methods}

\subsection{Water Sample Collection}

There are a total nine water treatment plants (WTPs) in the Langat River Basin that provide drinking water to one-third of the population in Selangor State of Malaysia [33] through the water distributor Syarikat Bekalan Air Selangor Sdn Bhd (SYABAS). Although each WTP has been designed to supply treated water in the specific areas of the basin, however, during water shortages treated water from one plant may be channeled to the areas of other plants using the same pipeline. Therefore, twenty liter water samples were collected in polyethylene containers from the Langat River precisely from where the WTPs are located, except the Semenyih WTP were we could not collect samples of raw water for treatment purposes in 2015 (Figure 1) during the rainy days. Similarly, twenty liter treated water samples were collected from the outlets of the WTPs on the same day of the raw water collection. Twenty liters of tap water from five households in the basin as well as three liters of water after filtration were also collected from the same households based on five types of household water filtration systems commonly used in the basin during the same period. Moreover, the collected water samples were analyzed before the end of the half-life of Po-210 i.e., 138 days. Overall, no special measures have been taken to analyze the samples.

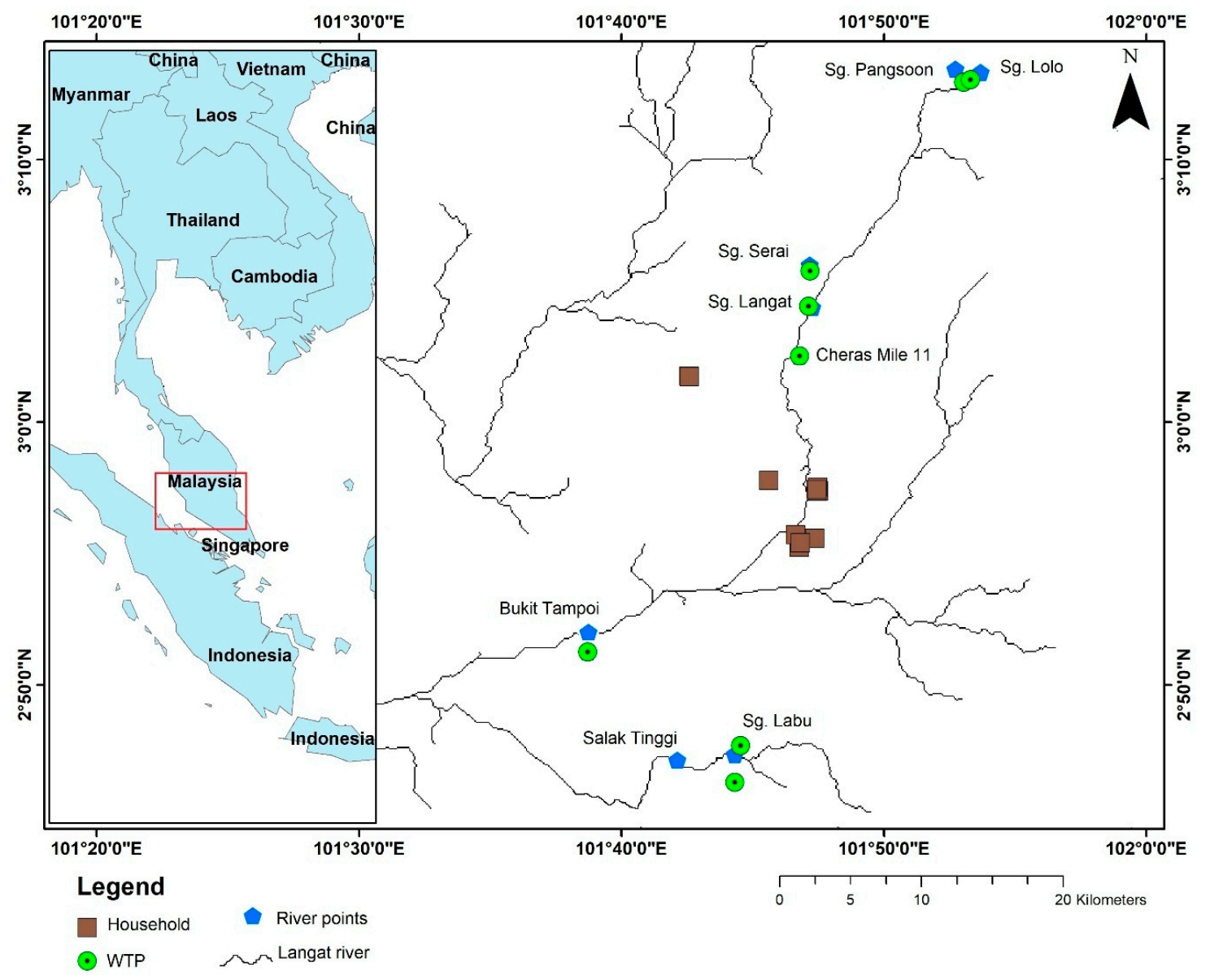

Figure 1. Water sampling points at Langat River Basin, Malaysia.

\subsection{Analysis of Po-210}

Water samples were filtered with the ADVANTEC membrane filter (pore size: $0.45 \mu \mathrm{m}$ ) and acidified with concentrated $\mathrm{HNO}_{3}$ immediately after collection in order to maintain $\mathrm{pH} \leq 2$ and to avoid contamination. Then the water samples were analyzed for Po-210 following the modified 
International Atomic Energy Agency (IAEA) method of $\mathrm{FeOH}_{2}$ precipitation (Figure 2) [38,39]. Similarly, the activity concentrations of Po-210 in water samples were determined by a CANBERRA Apex Alpha Spectrometer (Canberra Industries, Meriden, CT, USA) with a minimum detectable activity (MDA) of less than $0.2 \mathrm{mBq}$ for a counting efficiency of $12.79 \%$.

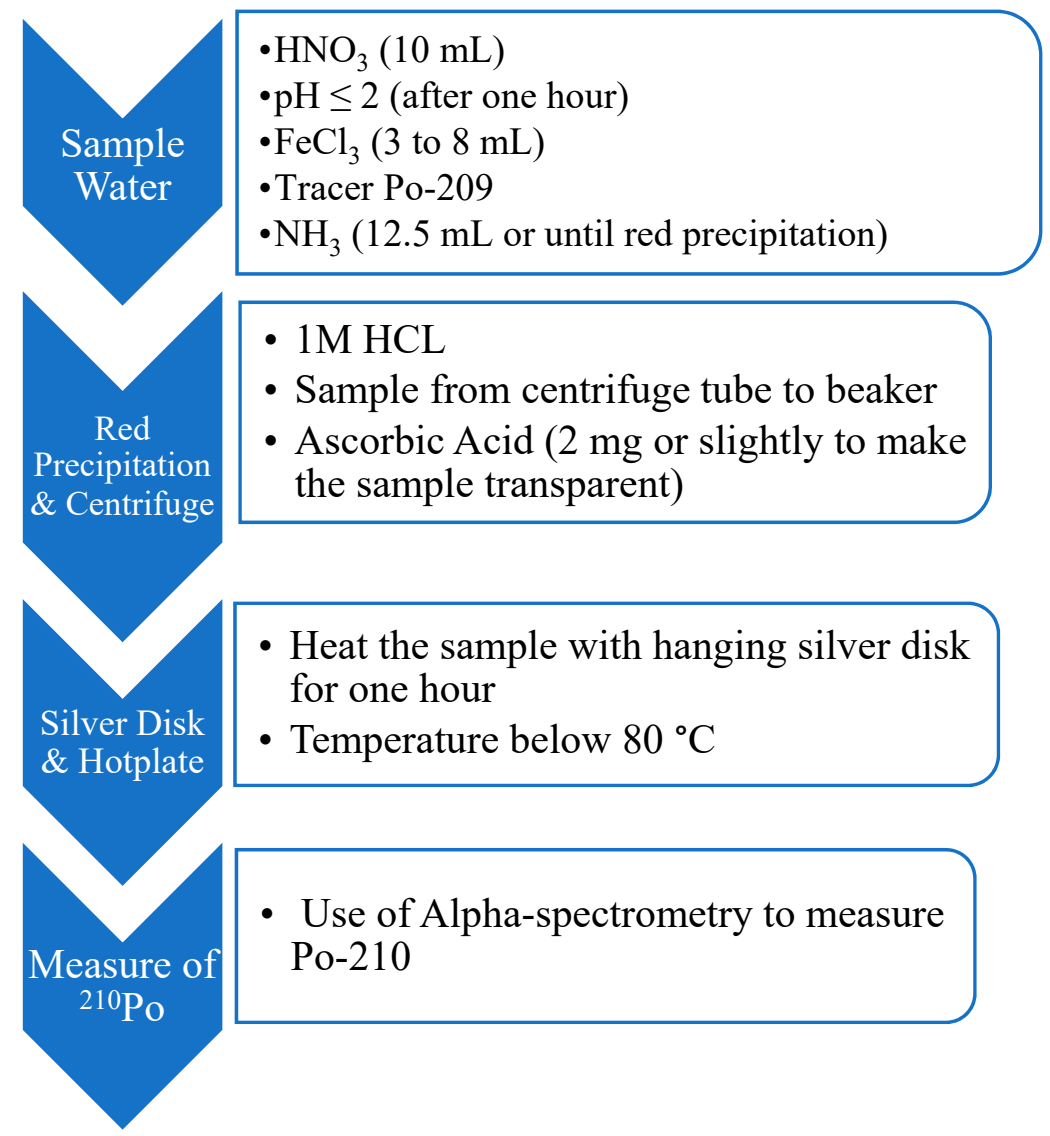

Figure 2. Steps of chemical analysis of Po-210 for fresh water sample [38].

A Po-210 tracer has been used in this study to calculate the recovery though using Equation (1) [40]. Po-209 Recovery $(\%)=[\{\mathrm{cpm}($ tracer $) /$ Counting Efficiency $\} /$ Spiked tracer Po-209 $(\mathrm{dpm})] \times 100$

Therefore, the following amounts of tracer Po-209 have been spiked for each sample (Table 1).

Table 1. Amount of Spiked Po-209 Tracer.

\begin{tabular}{|c|c|c|c|}
\hline Sample & $\begin{array}{l}\text { Spiked Weight of } \\
\text { Po-209 (g) }\end{array}$ & $\begin{array}{c}\text { Stock Tracer Po-209 } \\
\text { (dpm/g) }\end{array}$ & $\begin{array}{l}\text { Spiked Tracer } \\
\text { Po-209 (dpm) }\end{array}$ \\
\hline Pangsoon River & 0.2893 & 12.17 & 3.52 \\
\hline Pangsoon WTP & 0.4296 & 1.43 & 0.61 \\
\hline Lolo River & 0.2957 & 12.17 & 3.60 \\
\hline Lolo WTP & 0.3036 & 12.17 & 3.69 \\
\hline Serai River & 0.4987 & 12.17 & 6.07 \\
\hline Serai WTP & 0.3506 & 1.43 & 0.50 \\
\hline Langat River & 0.2643 & 12.17 & 3.22 \\
\hline Langat WTP & 0.4629 & 12.17 & 5.63 \\
\hline Cheras River & 0.4695 & 12.17 & 5.71 \\
\hline Cheras WTP & 0.4711 & 12.17 & 5.73 \\
\hline Bukit River & 0.3597 & 12.17 & 4.38 \\
\hline
\end{tabular}


Table 1. Cont.

\begin{tabular}{cccc}
\hline Sample & $\begin{array}{c}\text { Spiked Weight of } \\
\text { Po-209 } \mathbf{( g )}\end{array}$ & $\begin{array}{c}\text { Stock Tracer Po-209 } \\
\text { (dpm/g) }\end{array}$ & $\begin{array}{c}\text { Spiked Tracer } \\
\text { Po-209 (dpm) }\end{array}$ \\
\hline Bukit WTP & 0.4844 & 12.17 & 5.90 \\
Salak River & 0.2297 & 12.17 & 2.80 \\
Salak WTP & 0.4430 & 12.17 & 5.39 \\
Labu River & 0.2030 & 1.43 & 0.29 \\
Labu WTP & 0.4896 & 12.17 & 5.96 \\
Carbon Supply Hentian Kajang & 0.2768 & 12.17 & 3.37 \\
Carbon Filter Hentian Kajang & 0.2186 & 12.17 & 2.66 \\
Distilled Supply UKM & 0.2090 & 1.43 & 0.30 \\
Distilled Filter UKM & 0.1940 & 12.17 & 2.36 \\
RO Supply Hentian Kajang & 0.3646 & 12.00 & 4.38 \\
RO Filter Hentian Kajang & 0.2097 & 12.00 & 2.52 \\
Alkaline Supply Serdand & 0.3289 & 12.17 & 4.00 \\
Alkaline Filter Serdand & 0.3251 & 12.17 & 3.96 \\
UV Supply UKM & 0.1880 & 12.17 & 2.29 \\
UV Filter UKM & 0.3090 & 12.17 & 3.76 \\
\hline
\end{tabular}

\subsection{Calculating Po-210 Activity}

Equation (2) [40] has been used to calculate the activity of Po-210 in the water sampling date (Table 2):

$$
A_{0}=\frac{\mathrm{A}}{e^{-\lambda t}}
$$

where $A_{0}=$ Po-210 activity during sampling date, $A=$ Po-210 activity during counting date in alpha-spectrometry, $\lambda=$ Coefficient value of Po-210 is 0.005 per year, $t=$ Half-life of Po-210 is 138 days

Table 2. Tracer Po-209 recovery (\%) in drinking water supply chain samples in the Langat Basin.

\begin{tabular}{|c|c|c|c|c|}
\hline Location & Water (L) & Recovery Po-209 (\%) & Sampling Date & Test Date \\
\hline Pangsoon River & 20 & 19.68 & $6 / 8 / 2015$ & $22 / 12 / 2015$ \\
\hline Pangsoon WTP & 20 & 26.43 & $6 / 8 / 2015$ & $22 / 12 / 2015$ \\
\hline Lolo River & 20 & 19.27 & $6 / 8 / 2015$ & $22 / 12 / 2015$ \\
\hline Lolo WTP & 20 & 33.36 & $6 / 8 / 2015$ & $22 / 12 / 2015$ \\
\hline Serai River & 20 & 15.92 & $20 / 8 / 2015$ & 2/1/2016 \\
\hline Serai WTP & 20 & 58.84 & $20 / 8 / 2015$ & $28 / 12 / 2015$ \\
\hline Langat River & 20 & 25.96 & $11 / 8 / 2015$ & $22 / 12 / 2015$ \\
\hline Langat WTP & 20 & 20.13 & $11 / 8 / 2015$ & $22 / 12 / 2015$ \\
\hline Cheras River & 20 & 28.70 & $12 / 8 / 2015$ & $26 / 12 / 2015$ \\
\hline Cheras WTP & 20 & 12.87 & $12 / 8 / 2015$ & $24 / 12 / 2015$ \\
\hline Bukit River & 20 & 16.84 & $13 / 8 / 2015$ & $26 / 12 / 2015$ \\
\hline Bukit WTP & 20 & 25.23 & $13 / 8 / 2015$ & $22 / 12 / 2015$ \\
\hline Salak River & 20 & 14.38 & $14 / 8 / 2015$ & $23 / 1 / 2016$ \\
\hline Salak WTP & 20 & 11.37 & $14 / 8 / 2015$ & $22 / 12 / 2015$ \\
\hline Labu River & 20 & 19.70 & $20 / 8 / 2015$ & 2/1/2016 \\
\hline Labu WTP & 20 & 20.62 & $20 / 8 / 2015$ & 2/1/2016 \\
\hline Carbon Supply Hentian Kajang & 3 & 44.09 & $20 / 11 / 2015$ & $28 / 12 / 2015$ \\
\hline Carbon Filter Hentian Kajang & 3 & 18.81 & $20 / 11 / 2015$ & $28 / 12 / 2015$ \\
\hline Distilled Supply UKM & 3 & 30.22 & $20 / 11 / 2015$ & $26 / 12 / 2015$ \\
\hline Distilled Filter UKM & 3 & 23.83 & $5 / 5 / 2016$ & $22 / 6 / 2016$ \\
\hline RO Supply Hentian Kajang & 3 & 40.20 & $18 / 11 / 2015$ & $24 / 12 / 2015$ \\
\hline RO Filter Hentian Kajang & 3 & 31.94 & $18 / 11 / 2015$ & $24 / 12 / 2015$ \\
\hline Alkaline Supply Serdang & 3 & 23.43 & $15 / 11 / 2015$ & $30 / 1 / 2016$ \\
\hline Alkaline Filter Serdang & 3 & 26.78 & $15 / 11 / 2015$ & $30 / 1 / 2016$ \\
\hline UV Supply UKM & 3 & 13.38 & $15 / 11 / 2015$ & $30 / 1 / 2016$ \\
\hline Carbon Supply Hentin Kajang & 3 & 44.09 & $20 / 11 / 2015$ & $28 / 12 / 2015$ \\
\hline Carbon Filter Hentian Kajang & 3 & 18.81 & $20 / 11 / 2015$ & $28 / 12 / 2015$ \\
\hline
\end{tabular}

Note: WTP = Water Treatment Plant. 
Equation (3) [38] has been used to calculate the Po-210 activity in the counting date of samples by Alpha-spectrometry:

$$
\mathrm{A}=\{\text { cpm }(\text { sample }) / \text { cpm }(\text { tracer })\} \times[\{\text { Spiked tracer Po-209 }(\mathrm{dpm})\} \times\{1 / \text { Volume of sample }(\mathrm{L})\}]
$$

where, $\mathrm{cpm}=$ Counts per minute; Spiked trace Po-209 $(\mathrm{dpm})=\{$ Spiked weight of tracer Po-209 $(\mathrm{g}) \times$ Stock of trace Po-209 (dpm/g)\}; dpm = Disintegrations per minute.

\subsection{Calculating Annual Effective Dose of Po-210}

The annual effective dose of Po-210 to an individual due to ingestion through drinking water was estimated using Equation (4) [24,36]:

$$
\mathrm{D}_{\mathrm{w}}=\mathrm{C}_{\mathrm{w}} \times \mathrm{CR}_{\mathrm{w}} \times \mathrm{Dc}_{\mathrm{w}}
$$

where $D_{w}=$ Annual effective dose (mSv/year), $C_{w}=$ Activity of Po-210 in the ingested water $(\mathrm{Bq} / \mathrm{L})$, $\mathrm{CR}_{\mathrm{W}}=$ Annual intake of drinking water (i.e., average $1.996 \mathrm{~L} /$ Day by an individual in the Langat Basin through questionnaire survey, so $728.54 \mathrm{~L} /$ year) and $\mathrm{Dc}_{\mathrm{w}}=$ Ingested dose conversion factor for Po-210, which is $1.2 \times 10^{-3} \mathrm{mSv} / \mathrm{Bq}$ based on the report of International Commission on Radiological Protection (ICRP) 1996 [41,42].

\subsection{Household Questionnaire Survey}

According to the latest population census by the Department of Statistic Malaysia, the total number of households [43] in the Langat River Basin (Malaysia) is 1,494,865. Therefore, 402 household questionnaire surveys were conducted in the basin using Equation (5) [44,45] to get the average daily drinking water intake by the population at the basin to calculate the annual effective dose of Po-210 ingestion through drinking water (Equation (4)).

$$
n=\frac{N}{1+N(e)^{2}}
$$

where $n=$ sample size; $N=$ population size; $e=$ level of precision, i.e., 0.05 at $95 \%$ confidence level.

\subsection{Time-Series Environmental Data}

Flood Incidents data (2005-2016) for the Langat River Basin and water flow data (2005-2015) in the Langat River are obtained from the Dept. of Drainage and Irrigation Malaysia. Similarly, rainfall data (2006-2015) for the basin was collected from the Malaysian Meteorological Department. These data are plotted in the graphs below to show their trends and influences on the Po-210 activity in the Langat River Basin.

\section{Results and Discussion}

\subsection{Po-210 Status in Raw and Treated Water}

Po-210 activity ranges in the river $0.63 \pm 0.29 \mathrm{mBq} / \mathrm{L}$ to $14.98 \pm 1.18 \mathrm{mBq} / \mathrm{L}$ and treated water $0.34 \pm 0.10 \mathrm{mBq} / \mathrm{L}$ to $6.80 \pm 0.71 \mathrm{mBq} / \mathrm{L}$ (Table 3) of water treatment plants (WTPs) were within the maximum limit of raw and drinking water quality guideline of the Ministry of Health Malaysia [32] and the World Health Organization [41] i.e., $0.1 \times 10^{3} \mathrm{mBq} / \mathrm{L}$. Although Po-210 status in raw $(t=3.22$, $p=0.015)$ and treated water $(t=2.924, p=0.022)$ was significantly safe at $95 \%$ confidence level (i.e., $t$ statistic) through drinking water, however, the overall efficiency of all the WTPs in the basin was about $59 \%$ which might be due to an inability to remove Po-210 from treated water by the conventional method used at the plants as well as the small number of water samples. The Serai and Langat WTPs have the higher Po-210 removal efficiencies from treated water, about $93 \%$ and $81 \%$, respectively, 
might be because of lower iron concentration $(175 \mu \mathrm{g} / \mathrm{L})$ in the upstream region of the Langat River than the downstream $(264 \mu \mathrm{g} / \mathrm{L})$ [46] along with higher manganese and total dissolved solids at the downstream $[47,48]$, although all the WTPs in the basin follow a conventional coagulation method.

Table 3. Po-210 activity $(\mathrm{mBq} / \mathrm{L})$ in raw and treated water at the Langat River Basin.

\begin{tabular}{|c|c|c|c|c|}
\hline Location & River & WTP & Efficiency WTP (\%) & Weighted ${ }^{1}$ Efficiency \\
\hline Pangsoon & $2.99 \pm 0.33$ & $1.22 \pm 0.49$ & 59 & 3.72 \\
\hline Lolo & $2.54 \pm 0.31$ & $1.83 \pm 0.20$ & 28 & 1.49 \\
\hline Serai & $5.02 \pm 0.47$ & $0.34 \pm 0.10$ & 93 & 9.83 \\
\hline Langat & $14.98 \pm 1.18$ & $2.86 \pm 0.31$ & 81 & 25.49 \\
\hline Cheras & $12.40 \pm 0.84$ & $6.80 \pm 0.71$ & 45 & 11.77 \\
\hline Bukit & $7.14 \pm 0.69$ & $5.18 \pm 0.42$ & 27 & 4.12 \\
\hline Salak & $1.86 \pm 0.45$ & $0.84 \pm 0.20$ & 55 & 2.14 \\
\hline Labu & $0.63 \pm 0.29$ & $0.51 \pm 0.11$ & 20 & 0.26 \\
\hline Mean & $5.95 \pm 5.22$ & $2.45 \pm 2.37$ & 59 & 58.83 (Total) \\
\hline$t$ value & 3.220 & 2.924 & & \\
\hline$p$ value & $0.015 *$ & 0.022 * & & \\
\hline MOH (2010) & \multicolumn{2}{|c|}{$<0.1 \times 10^{3} \mathrm{mBq} / \mathrm{L}$} & & \\
\hline WOH (2017) & \multicolumn{2}{|c|}{$<0.1 \times 10^{3} \mathrm{mBq} / \mathrm{L}$} & & \\
\hline
\end{tabular}

Sources of Po-210 in the Langat River

The Langat River originates at the hilly areas of Hulu Langat, Selangor, Malaysia that are an extension of the Titiwangsa Mountain Range at the north of Selangor. Hence the river drains towards west via the highly urbanized areas of Malaysia until it flows into the Strait of Malacca. Granite rock, extended from the granite batholith of Peninsular Thailand, is widespread underneath central Peninsular Malaysia, especially the entire Selangor state that is situated on two types of lithology based on intrusive rock, i.e., the formation is mainly from gabbro $>500$ million years ago [2,3]. Therefore, the mean dose rate of soil in Selangor is $183 \pm 84 \mathrm{nGy} / \mathrm{h}$ with the range of $17.4 \mathrm{nGy} / \mathrm{h}$ to $500 \mathrm{nGy} / \mathrm{h}$ and the mean value is two times higher than the rest of Malaysia as well as the world average (i.e., $92 \mathrm{nGy} / \mathrm{h}$ ) [3]. Moreover, a higher dose rate of $500 \mathrm{nGy} / \mathrm{h}$ has been recorded in Hulu Gombak because of its location in the acid intrusive granite rock in the Titiwangsa Mountain Range of East Selangor (Figure 3). Hence, through several steps such as weathering, erosion, etc. of granite, quartz rocks [4], these natural radionuclides usually migrate into the Langat River and increase the activity of radionuclides.

However, the higher Po-210 activity in the midstream of Langat River than the upstream might be due to the aerial inputs of the radionuclide, accumulation of radionuclide-rich silt and organic matter, and increased biological production [50] as well as agricultural, industrial and urban waste discharge in the river [51]; since dissolved oxygen (DO) along with a declining trend (Table 4) and conductivity shows a strongly significant inverse correlation $(r=-0.811)$ at $99 \%$ confidence level (Table 5).

Table 4. Results of the Linear Regression-based Trend line of Po-210, Physiochemical and Environmental Parameters.

\begin{tabular}{ccccc}
\hline Parameters & Constant & River Point Coefficient & R-Square & F-Stat \\
\hline Po-210 & $6.81(1.56)$ & $-0.09(-0.22)$ & 0.01 & $0.05(0.832)$ \\
DO & $10.66(17.43)$ & $-0.95(-7.63)$ & 0.91 & $58.21(0.0003)$ \\
Salinity & $0.001(0.61)$ & $0.85(4.01)$ & 0.73 & $16.09(0.007)$ \\
Water Flow & $-6.99(-1.09)$ & $0.89(4.72)$ & 0.79 & $22.28(0.003)$ \\
Rainfall & $3079.94(22.62)$ & $-0.81(-3.43)$ & 0.66 & $11.79(0.014)$ \\
Flood Incidents & $13.24(10.56)$ & $-0.74(-2.70)$ & 0.55 & $7.27(0.036)$ \\
\hline
\end{tabular}



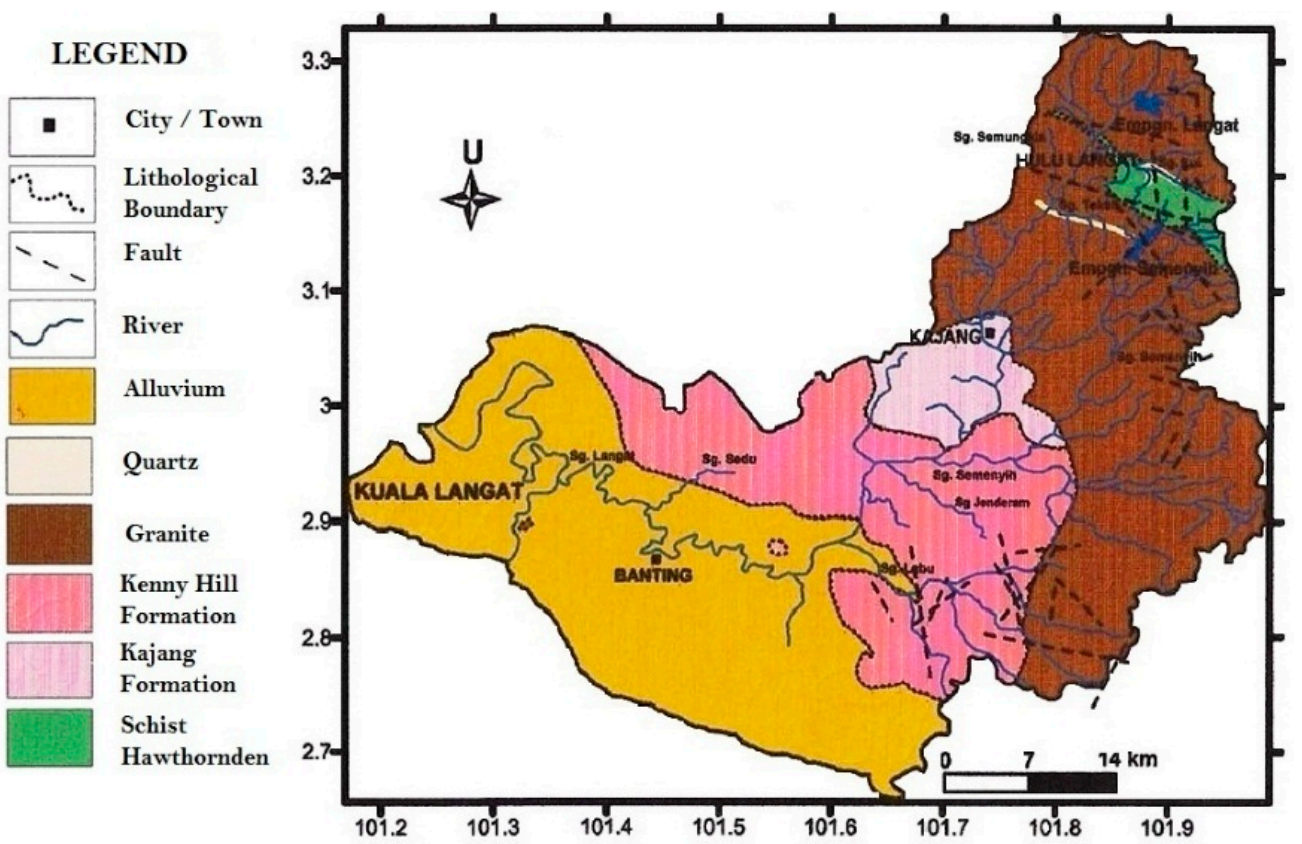

Figure 3. Geological map of Langat River Basin, Malaysia [4].

Table 5. Correlation of water quality and environmental parameters in Langat River.

\begin{tabular}{|c|c|c|c|c|c|c|c|c|c|}
\hline \multicolumn{2}{|c|}{ Parameters } & \multirow{2}{*}{$\begin{array}{c}\text { Po-210 } \\
1\end{array}$} & \multirow[t]{2}{*}{ Salinity } & \multirow[t]{2}{*}{ DO } & \multirow[t]{2}{*}{ Conductivity } & \multicolumn{2}{|c|}{ Temperature Flood } & \multirow[t]{2}{*}{ Rainfall } & \multirow[t]{2}{*}{ Water Flow } \\
\hline Po-210 & $\begin{array}{c}\text { Pearson } \\
\text { Correlation } \\
\text { Sig. (1-tailed) }\end{array}$ & & & & & & & & \\
\hline Salinity & $\begin{array}{c}\text { Pearson } \\
\text { Correlation } \\
\text { Sig. (1-tailed) }\end{array}$ & $\begin{array}{l}0.043 \\
0.459\end{array}$ & 1 & & & & & & \\
\hline DO & $\begin{array}{c}\text { Pearson } \\
\text { Correlation } \\
\text { Sig. (1-tailed) }\end{array}$ & $\begin{array}{l}0.244 \\
0.280\end{array}$ & $\begin{array}{c}-0.800^{* * *} \\
0.009\end{array}$ & 1 & & & & & \\
\hline Conductivity & $\begin{array}{c}\text { Pearson } \\
\text { Correlation } \\
\text { Sig. (1-tailed) }\end{array}$ & $\begin{array}{l}0.016 \\
0.485\end{array}$ & $\begin{array}{c}0.995^{* * *} \\
0.000\end{array}$ & $\begin{array}{c}-0.811^{* * *} \\
0.007\end{array}$ & 1 & & & & \\
\hline Temperature & $\begin{array}{c}\text { Pearson } \\
\text { Correlation } \\
\text { Sig. (1-tailed) }\end{array}$ & $\begin{array}{l}0.161 \\
0.352\end{array}$ & $\begin{array}{c}0.819^{* * *} \\
0.006\end{array}$ & $\begin{array}{c}-0.852^{* * *} \\
0.004\end{array}$ & $\begin{array}{c}0.824^{* * *} \\
0.006\end{array}$ & 1 & & & \\
\hline Flood & $\begin{array}{c}\text { Pearson } \\
\text { Correlation } \\
\text { Sig. (1-tailed) }\end{array}$ & $\begin{array}{c}0.542 \text { * } \\
0.083\end{array}$ & $\begin{array}{c}-0.287 \\
0.245\end{array}$ & $\begin{array}{c}0.743 \text { * } \\
0.017\end{array}$ & $\begin{array}{c}-0.318 \\
0.222\end{array}$ & $\begin{array}{c}-0.533 \\
0.087\end{array}$ & 1 & & \\
\hline Rainfall & $\begin{array}{c}\text { Pearson } \\
\text { Correlation } \\
\text { Sig. (1-tailed) }\end{array}$ & $\begin{array}{c}0.553 \text { * } \\
0.077\end{array}$ & $\begin{array}{c}-0.546 \\
0.081\end{array}$ & $\begin{array}{c}0.900^{* * *} \\
0.001\end{array}$ & $\begin{array}{c}-0.556 \\
0.076\end{array}$ & $\begin{array}{c}-0.657^{* *} \\
0.038\end{array}$ & $\begin{array}{c}0.922 * * \\
0.001\end{array}$ & 1 & \\
\hline Water Flow & $\begin{array}{c}\text { Pearson } \\
\text { Correlation } \\
\text { Sig. (1-tailed) }\end{array}$ & $\begin{array}{c}-0.370 \\
0.184\end{array}$ & $\begin{array}{c}0.838^{* * *} \\
0.005\end{array}$ & $\begin{array}{c}-0.867^{* * *} \\
0.003\end{array}$ & $\begin{array}{c}0.850^{* * *} \\
0.004\end{array}$ & $\begin{array}{c}0.815^{* * *} \\
0.007\end{array}$ & $\begin{array}{c}-0.609 \\
0.054\end{array}$ & $\begin{array}{c}-0.805^{* * *} \\
0.008\end{array}$ & 1 \\
\hline
\end{tabular}

*** Correlation is significant at the 0.01 level (1-tailed); ${ }^{* *}$ Correlation is significant at the 0.05 level (1-tailed).

* Correlation is significant at the 0.10 level (1-tailed).

Moreover, human activities such as mining, aquaculture, agriculture, and industrial effluent discharged into the water also contribute to enhancing the levels of radionuclides in the water body [52]. Contrary, the inadequate collaboration among agencies has made the pollution management of river very complex since the river drains through three different constituencies $[53,54]$. Therefore, the lower Po-210 activity in the raw water at the upstream of Langat River might be due to higher DO as well as non-conservative characteristics of Po-210 $[38,55]$. Therefore, both the DO $(b=-0.95, p<0.01)$ and 
Po-210 $(b=-0.09, p>0.10)$ show declining trends based on the linear regression (Figure 4, Table 4) from upstream to downstream at the Langat River. However, salinity $(b=0.85, p<0.01)$ shows an increasing trend from upstream to downstream at the Langat River. It indicates that the Po-210 might have precipitated due to the increasing salinity towards downstream while mixing with the sea water.

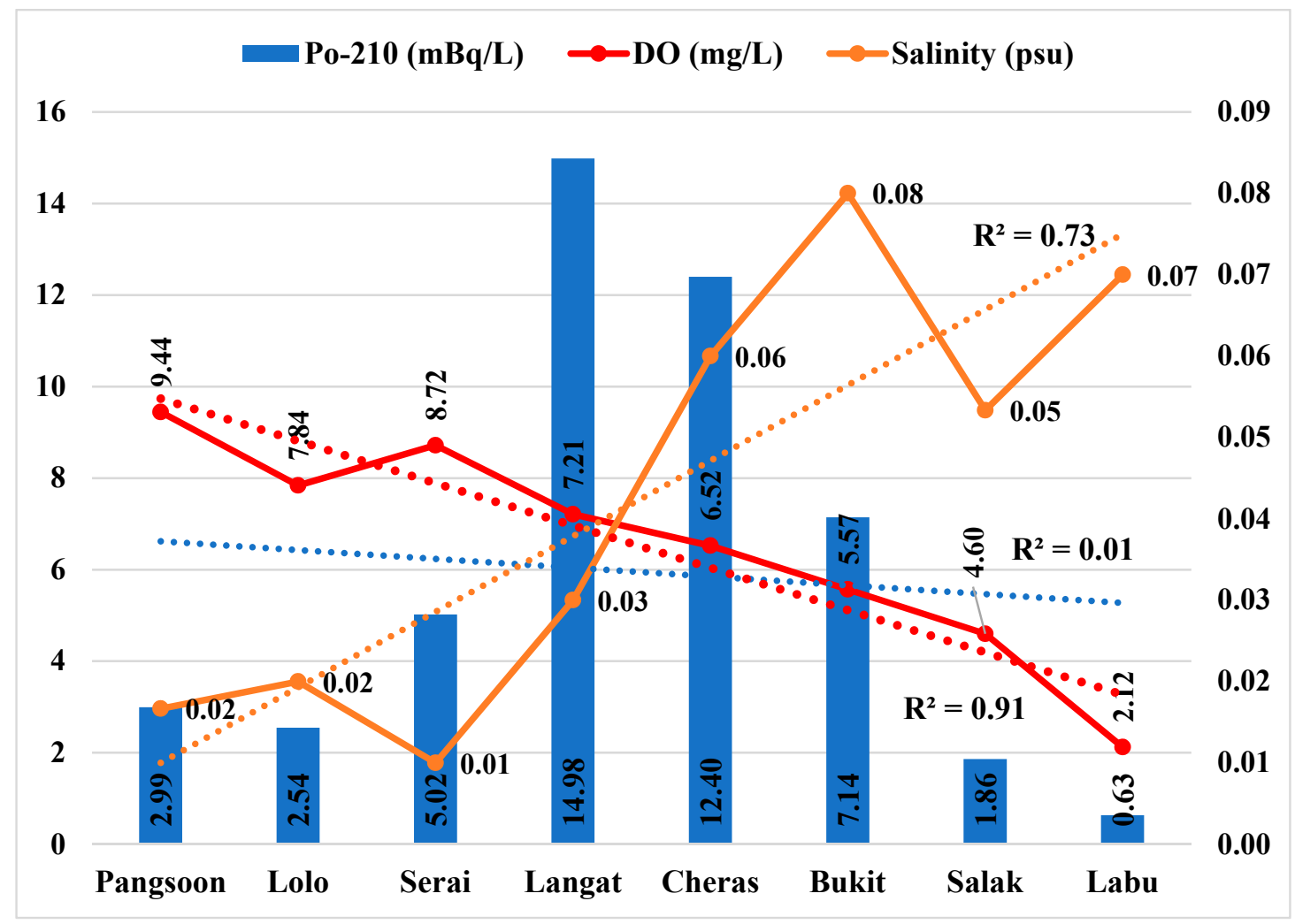

Figure 4. Po-210 activity in Langat River in relation with environmental parameters. Note: $\mathrm{R}^{2}$ indicates the variance that is explained by the best-fit line from the upstream to the downstream of the Langat River.

Similarly, the increasing water flow $(b=0.89, p<0.01)$ at the downstream (Figure 5, Table 4) might have also diluted Po-210 activity in dissolved phase. Moreover, Po-210 activity and water flow in the Langat River show a negative correlation $(r=-0.370$; Table 3$)$. However, the declining rainfall trend $(b=-0.81, p<0.01)$ (Figure 6, Table 4) and flood incidents $(b=-0.74, p<0.05)$ (Figure 7, Table 4) trend towards downstream of Langat River indicates less atmospheric and terrestrial inputs to have lower Po-210 activity towards downstream than the upstream to midstream. Therefore, Po-210 activity shows a positive correlation (Table 5$)$ with rainfall $(r=0.553 ; p=0.077)$ and flood incidents $(r=0.542$; $p=0.083$ ) that means there will be lower Po-210 activity in Langat River if there are less rainfall and flood incidents.

Table 3 describes the influence of environmental and physiochemical parameters on the Po-210 activity in the Langat River. Significant positive correlations between Po-210 activity and rainfall $\left(r=0.553^{*}\right)$ as well as Po-210 activity and flood incidents $\left(r=0.542^{*}\right)$ are observed at the 0.10 level, respectively, in the Langat River, that might be because of their decreasing trends towards downstream. The decreasing trend of rainfall during 2005 to 2016 (Figure 6) and flood incidents during 2004 to 2016 (Figure 7) in the Langat River from upstream to downstream also supports the positive correlations between Po-210 and rainfall as well as Po-210 and flood incidents since there are less atmospheric and terrestrial inputs into the river. Accordingly, based on the geochemical behavior of Po-210, it precipitates toward downstream while mixing with the sea water [56]. Therefore, these findings indicate when there is less terrestrial runoff in Langat River, then there might be less attribution from natural and manmade sources to have lower Po-210 activity in raw water. 


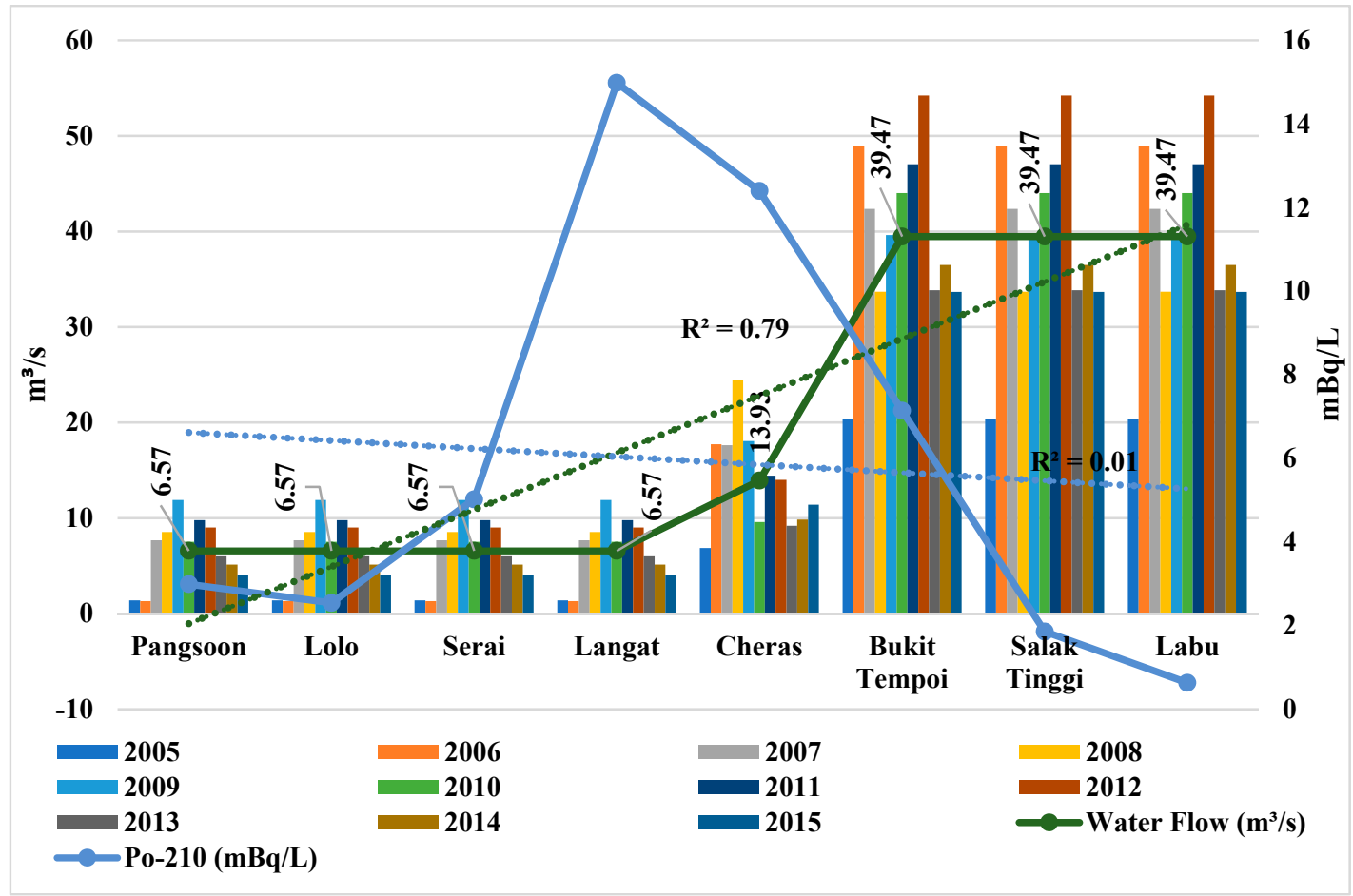

Figure 5. Po-210 activity in Langat River in relation with water flow in the Langat River. Note: Average water flow data (2005-2015) are from the Dept. of Drainage and Irrigation Malaysia. $\mathrm{R}^{2}$ indicates the variance that is explained by the best-fit line from the upstream to the downstream of the Langat River.

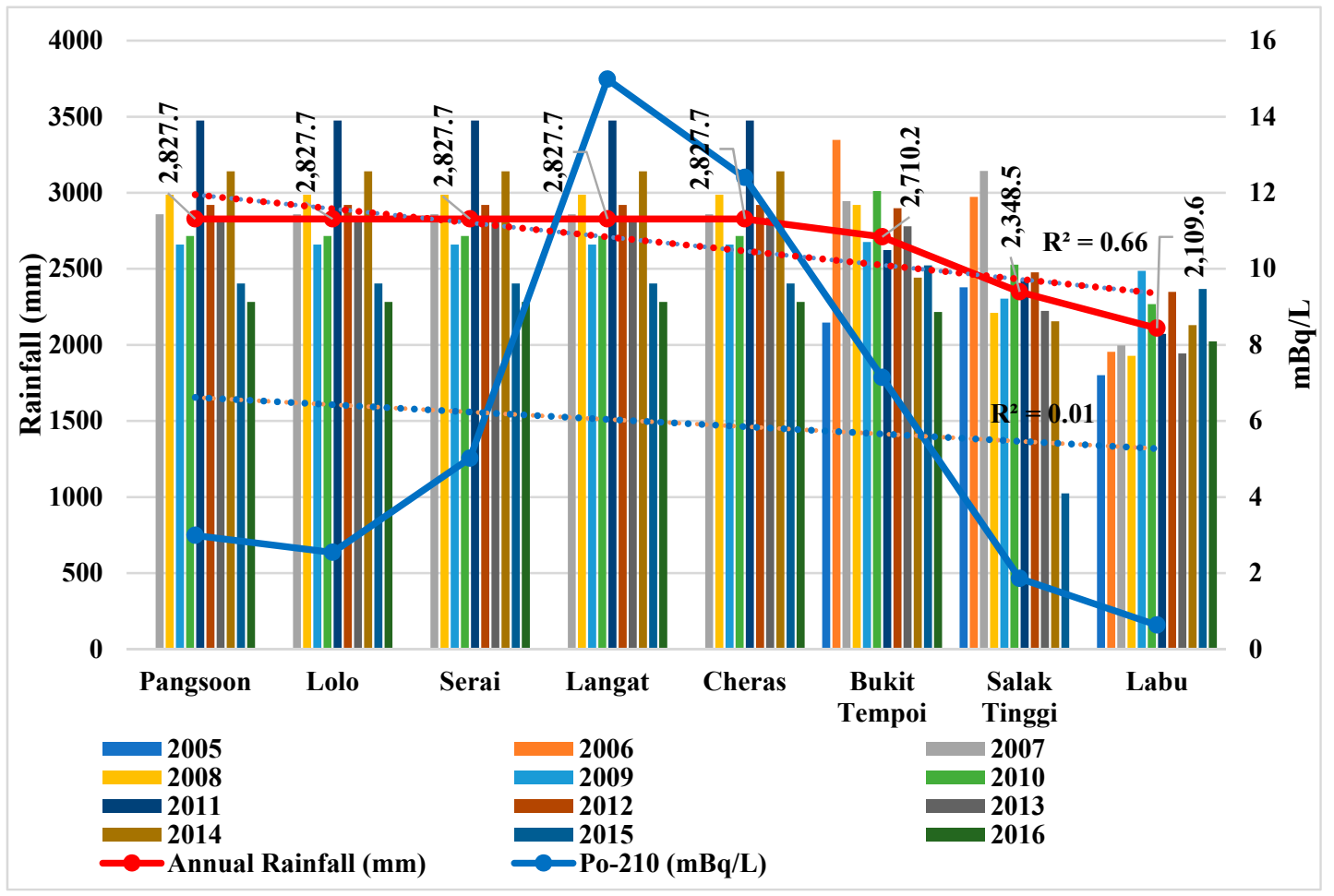

Figure 6. Po-210 activity in Langat River in relation with rainfall in the Langat Basin. Note: Mean rainfall data (2006-2015) from the Malaysian Meteorological Department. $R^{2}$ indicates the variance that is explained by the best-fit line from the upstream to the downstream of the Langat River. 


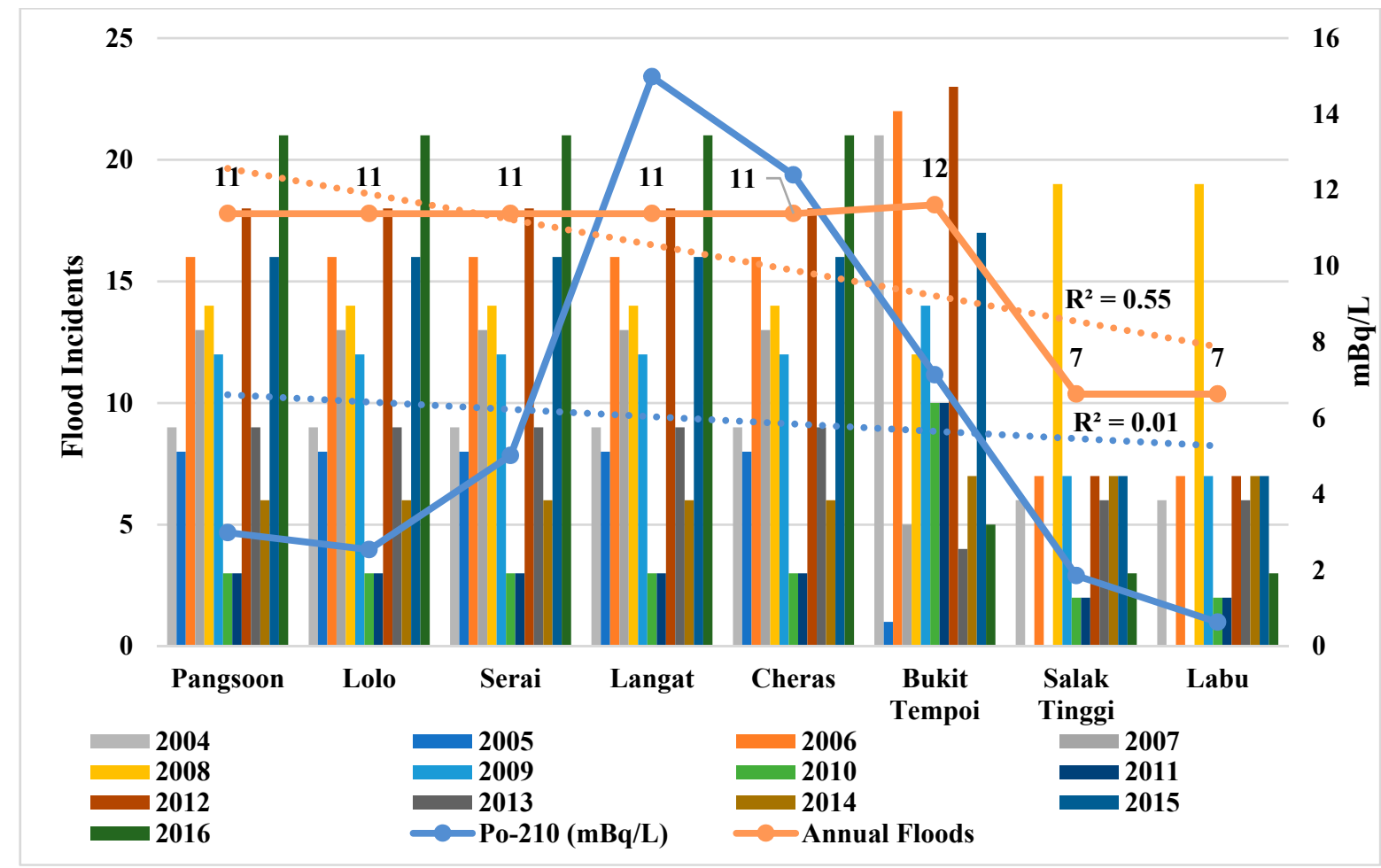

Figure 7. Po-210 activity in Langat River in relation with flood incidents in the Langat Basin. Note: Average flood Incidents data (2005-2016) from the Dept. of Drainage and Irrigation Malaysia. $\mathrm{R}^{2}$ indicates the variance that is explained by the best-fit line from the upstream to the downstream of the Langat River.

The activity of Po-210, U-238 decay series progeny, i.e., $14.98 \pm 1.18 \mathrm{mBq} / \mathrm{L}$, in the Langat River is higher among many rivers around the world (Table 6); this might be because the river runs through a former tin mining area that can be the source of Naturally Occurring Radioactive Materials (NORM) [57,58]. The other reasons for the enhanced Po-210 activity in the Langat River might be due to the weathering process on the granitic formation of the river basin, the origin of the water, flow rate, flux of radionuclides, and geological characteristics of the area along with haze events in dry seasons $[59,60]$. The sources of radionuclide pollutants are also from fertilizers, tin mining, aquaculture feed [61] and industries [57]. Similarly, the higher Po-210 activity in the Vistula River, Poland $0.5 \pm 0.1$ to $9.8 \pm 0.02 \mathrm{mBq} / \mathrm{L}$, is mainly because of higher contamination from phosphate fertilizer and coal mining, along with natural sources [62].

However, the world average activity of Po-210 in the drinking water from private wells is 7 to $48 \mathrm{mBq} / \mathrm{L}$ [63]. In Malaysia, rivers provide about $98 \%$ of the drinking water sources $[64,65]$ and in the case of the Langat River, it provides drinking water to over one-third of the population in the state of Selangor $[47,66]$. Therefore, the annual effective doses through ingestion of Po-210 by drinking water could be dangerous for human health.

Moreover, among the rivers of Malaysia, the annual effective dose of Po-210 from the Langat River is estimated the highest, i.e., $1.31 \times 10^{-2} \mathrm{mSv}$ /year (Table 7), because the river is located in a high rich uranium granite rock belt, although it is below the standard of $0.01 \mathrm{mSv} /$ year. Comparison of the annual effective dose of Po-210 from the Langat River with other rivers around the world indicates that the Langat River is in the second position, while the Vistula River in Poland, i.e., $8.6 \times 10^{-3} \mathrm{mSv} /$ year, is in the first position [62]. 
Table 6. Activity of Po-210 (mBq/L) both in Malaysian and various rivers of the world.

\begin{tabular}{cccc}
\hline River (Year) & Minimum & Maximum & References \\
\hline Langat, Malaysia & $0.63 \pm 0.29$ & $14.98 \pm 1.18$ & Present Study \\
\hline Langat, Malaysia (2015) & - & $7.70 \pm 0.60$ & {$[67]$} \\
\hline Kuala Selangor, Malaysia (2010) & $0.0002 \pm 0.0001$ & $0.014 \pm 0.003$ & {$[38]$} \\
\hline Kuala Selangor, Malaysia (2005) & $0.22 \pm 0.06$ & $0.75 \pm 0.28$ & [68] \\
\hline Vistula, Poland (2004) & $0.49 \pm 0.09$ & $9.80 \pm 0.02$ & \\
\hline Oder, Poland (2004) & $0.60 \pm 0.09$ & $5.21 \pm 0.19$ & \\
\hline Pomeranian, Poland (2004) & $3.82 \pm 0.24$ & $5.50 \pm 0.33$ & \\
\hline Yellow, China (1999) & $0.25 \pm 0.08$ & $1.55 \pm 0.50$ & \\
\hline Tagus, Portugal (1997) & $0.50 \pm 0.36$ & $0.67 \pm 0.03$ & [69] \\
\hline
\end{tabular}

Table 7. Annual effective dose of Po-210 (mSv/year) based on river water globally.

\begin{tabular}{cccc}
\hline Location (Year) & Minimum & Maximum & References \\
\hline Langat, Malaysia & $5.51 \times 10^{-4}$ & $1.31 \times 10^{-2}$ & Present Study \\
\hline Langat, Malaysia (2015) & - & $6.8 \times 10^{-3}$ & {$[67]$} \\
\hline Kuala Selangor, Malaysia (2010) & $0.0002 \times 10^{-3}$ & $0.01 \times 10^{-3}$ & {$[38]$} \\
\hline Kuala Selangor, Malaysia (2005) & $0.2 \times 10^{-3}$ & $0.7 \times 10^{-3}$ & {$[68]$} \\
\hline Vistula, Poland (2004) & $0.4 \times 10^{-3}$ & $8.6 \times 10^{-3}$ & \\
\hline Oder, Poland (2004) & $0.5 \times 10^{-3}$ & $4.6 \times 10^{-3}$ & [62] \\
\hline Pomeranian, Poland (2004) & $3.4 \times 10^{-3}$ & $4.8 \times 10^{-3}$ & \\
\hline Yellow, China (1999) & $0.2 \times 10^{-3}$ & $1.4 \times 10^{-3}$ & [69] \\
\hline Tagus, Portugal (1997) & $0.4 \times 10^{-3}$ & $0.6 \times 10^{-3}$ & [70] \\
\hline
\end{tabular}

\subsection{Po-210 Status in Household's Tap and Filtration Water}

Po-210 activity ranges in tap water $1.05 \pm 0.33 \mathrm{mBq} / \mathrm{L}$ to $22.35 \pm 1.67 \mathrm{mBq} / \mathrm{L}$ and filtration water $0.49 \pm 0.19 \mathrm{mBq} / \mathrm{L}$ to $7.30 \pm 0.84 \mathrm{mBq} / \mathrm{L}$ at the household level in the Langat Basin were fairly within the maximum limit of drinking water quality standard of $\mathrm{MOH}$ and $\mathrm{WHO}$ i.e., $<0.1 \times 10^{3} \mathrm{mBq} / \mathrm{L}$ (Table 8). However, the higher mean Po-210 activity in tap water than the raw and treated water indicates contamination in the drinking water distribution pipeline. Terrestrial inputs might have elevated the Po-210 activity in the tap water through the heavy repairing activities of the water distribution pipeline while water was mixing with the soil at Hentian Kajang and UKM areas within the basin. The soil in the granite rock of Peninsular Malaysia including the Langat River Basin highly influences the radioactivity of naturally occurring radionuclides [2,4]. Similarly, the small number of water samples might be one of the reasons of higher Po-210 activity in tap and filtration water as well as the standard deviations. Fortunately, the effectiveness of the household water filtration systems to remove Po-210 from the drinking water in the basin is about $74 \%$ (Table 6). Among the commonly used household water filtration systems in the basin, the ultraviolet (UV) filtration system shows higher efficiency (93\%) followed by distilled filtration system (69\%) in removing Po-210 from drinking water and the Po-210 activity in drinking water at Langat River Basin is within both the national and international drinking water quality guidelines. 
Table 8. Po-210 activity (mBq/L) in tap and filter water at Langat River Basin.

\begin{tabular}{cccccc}
\hline Location & Tap Water & Filter Type & Filtration Water & Efficiency Filter (\%) & Weighted ${ }^{\mathbf{1}}$ Efficiency \\
\hline Hentian Kajang & $1.33 \pm 0.25$ & Carbon & $1.05 \pm 0.33$ & 21 & 0.66 \\
UKM & $1.57 \pm 0.70$ & Distilled & $0.49 \pm 0.19$ & 69 & 2.55 \\
Hentian Kajang & $22.35 \pm 1.67$ & RO & $7.30 \pm 0.84$ & 67 & 35.51 \\
Serdang & $1.05 \pm 0.33$ & Alkaline & $0.87 \pm 0.28$ & 17 & 0.42 \\
UKM & $16.08 \pm 2.27$ & UV & $1.13 \pm 0.37$ & 93 & 74.28 \\
Mean & $8.48 \pm 10.10$ & Mean & $2.17 \pm 2.88$ & 74.42 (Total) \\
\hline$t$ value & 1.885 & $t$ value & 1.684 & \\
$p$ value & 1.32 & $p$ value & 1.68 & \\
MOH $(2010)$ & $<0.1 \times 10^{3} \mathrm{mBq} / \mathrm{L}$ \\
WOH $(2017)$ & $<0.1 \times 10^{3} \mathrm{mBq} / \mathrm{L}$ \\
\hline
\end{tabular}

Note: Reported Po-210 activity is in the sampling date $\left(\mathrm{A}_{\mathrm{o}}\right)$ and Calculation of standard deviation is based on the radiochemistry method, not on the replicates [49]. ${ }^{1}$ Sum of all the Po-210 activities in all the five-tap water has been taken as the basis of weighted average for each household water filtration system.

Ahmed et al. [67] reported that the Po-210 activity in the supplied water (1.7 mBq/L) in the Langat River Basin was slightly higher than the activity of the treated water $1.5 \mathrm{mBq} / \mathrm{L}$ at the outlet of water treatment plants might be due to the contamination in the pipelines of the drinking water supply system. Moreover, the activity of Po-210 in the supplied water in Malaysia is higher than many countries of the world such as $1.0 \mathrm{mBq} / \mathrm{L}$ in Italy [70], 2 to $15.2 \mathrm{mBq} / \mathrm{L}$ in Hungary [6], $0.48 \mathrm{mBq} / \mathrm{L}$ in Poland [71], $1.4 \mathrm{mBq} / \mathrm{L}$ in India [72], etc. (Table 9). On the other hand, Po-210 activity in the supplied water of USA $5 \mathrm{mBq} / \mathrm{L}$ [73], Italy $3.25 \mathrm{mBq} / \mathrm{L}$ [9] and Bombay, India $1.9 \mathrm{mBq} / \mathrm{L}$ [72] were higher than the Po-210 activity in the supplied water of Malaysia, 2015 (Table 7).

Table 9. Po-210 activity in household's tap water around the world.

\begin{tabular}{cccc}
\hline Location (Year) & Activity $(\mathbf{m B q} / \mathbf{L})$ & Dose $(\mathbf{m S v} /$ Year) & References \\
\hline Langat Basin & 8.48 & $7.41 \times 10^{-3}$ & Present Study \\
\hline Bangi, Malaysia (2015) & 1.7 & $1.5 \times 10^{-3}$ & {$[67]$} \\
\hline Italy (2009) & 3.25 & $2.84 \times 10^{-3}$ & {$[9]$} \\
\hline Italy (2007) & 1 & $0.9 \times 10^{-3}$ & {$[70]$} \\
\hline Hungary (2010) & 2 & $1.75 \times 10^{-3}$ & {$[6]$} \\
\hline Poland (2001) & 0.48 & $0.42 \times 10^{-3}$ & {$[71]$} \\
\hline India (2001) & 1.4 & $1.2 \times 10^{-3}$ & \\
\hline Bombay, India (1977) & 1.9 & $1.7 \times 10^{-3}$ & {$[72]$} \\
\hline Brazil (1992) & 1 & $0.9 \times 10^{-3}$ & \\
\hline Portugal (1995) & 0.21 & $0.2 \times 10^{-3}$ & \\
\hline Syria (1995) & 1 & $0.9 \times 10^{-3}$ & {$[74]$} \\
\hline Austria (2001) & 0.4 & $0.35 \times 10^{-3}$ & {$[73]$} \\
\hline USA (2008) & 5 & $4.4 \times 10^{-3}$ & \\
\hline
\end{tabular}

\subsection{Human Health Hazard of Po-210 Ingestion}

The annual effective doses of Po-210 through ingestion via drinking water are significant in terms of dose contributions. Although the radioactivity of Po-210 in drinking water is lower than the activity of the isotopes of uranium, however Po-210 is considered highly toxic. Moreover, Po-210 is the most important dose contributor through ingestion of drinking water. For instance, Jia et al. [9] investigated that the mean Po-210 activity $3.25 \mathrm{mBq} / \mathrm{L}$ and the Po-210 activity in drinking water remained in the last position in the series of U-238, Ra-228 and Pb-210, however in terms of annual effective dose $2.84 \times 10^{-3} \mathrm{mSv} /$ year Po-210 was the highest contributor in the same series of radionuclides (Table 9). 
Unfortunately, the Po-210 activity in the drinking water and its annual effective dose exposure for a long time to human beings has not been studied extensively due the difficulties in determining the radioactivity [19].

Therefore, the calculated annual effective dose of Po-210 ingestion via tap water $7.41 \times 10^{-3} \mathrm{mSv} /$ year and household filtration water $1.90 \times 10^{-3} \mathrm{mSv} /$ year indicate an acceptable carcinogenic risk for the populations at the Langat River Basin, since the values are within the standard of UNSCAER $<0.12 \mathrm{mSv} /$ year, WHO $<0.01 \mathrm{mSv}$ /year, and ICRP $<1.0 \mathrm{mSv} /$ year [36] and the Polish Ministry of Health $<0.01 \mathrm{mSv} /$ year [75,76] (Table 10). Although the higher standard deviations might be due to the small number of environmental samples, however, the result indicates safe for human consumption. Similarly, the annual effective dose of river $5.20 \times 10^{-3} \pm 4.56 \times 10^{-3} \mathrm{mSv} /$ year and treated water $2.14 \times 10^{-3} \pm 2.07 \times 10^{-3} \mathrm{mSv} /$ year were significantly within the standard limit at $95 \%$ confidence level.

Table 10. Annual effective dose of Po-210 via drinking water at Langat River Basin.

\begin{tabular}{ccccccc}
\hline Location & $\begin{array}{c}\text { River } \\
(\mathbf{m S v} / \text { Year) }\end{array}$ & $\begin{array}{c}\text { WTP } \\
(\mathbf{m S v} / \text { Year) }\end{array}$ & Location & $\begin{array}{c}\text { Tap } \\
(\mathbf{m S v} / \text { Year })\end{array}$ & Filter Type & $\begin{array}{c}\text { Filtered } \\
(\mathbf{m S v} / \text { Year) }\end{array}$ \\
\hline Pangsoon & $2.62 \times 10^{-3}$ & $1.07 \times 10^{-3}$ & Hentian Kajang & $1.16 \times 10^{-3}$ & Carbon Filter & $9.18 \times 10^{-4}$ \\
Lolo & $2.22 \times 10^{-3}$ & $1.6 \times 10^{-3}$ & UKM & $1.37 \times 10^{-3}$ & Distilled Filter & $4.28 \times 10^{-4}$ \\
Serai & $4.39 \times 10^{-3}$ & $3.01 \times 10^{-4}$ & Hentian Kajang & $1.95 \times 10^{-2}$ & RO Filter & $6.38 \times 10^{-3}$ \\
Langat & $1.31 \times 10^{-2}$ & $2.50 \times 10^{-3}$ & Serdang & $9.18 \times 10^{-4}$ & Alkaline Filter & $7.61 \times 10^{-4}$ \\
Cheras & $1.08 \times 10^{-2}$ & $5.94 \times 10^{-3}$ & UKM & $1.41 \times 10^{-2}$ & UV Filter & $9.88 \times 10^{-4}$ \\
Bukit & $6.24 \times 10^{-3}$ & $4.53 \times 10^{-3}$ & Average & $7.41 \times 10^{-3}$ & Average & $1.90 \times 10^{-3}$ \\
Salak & $1.63 \times 10^{-3}$ & $7.35 \times 10^{-4}$ & Std. & $8.78 \times 10^{-3}$ & Std. & $2.52 \times 10^{-3}$ \\
Labu & $5.52 \times 10^{-4}$ & $4.43 \times 10^{-4}$ & $t$ value & 1.886 & $t$ value & 1.684 \\
Average & $5.20 \times 10^{-3}$ & $2.14 \times 10^{-3}$ & $p$ value & 0.132 & $p$ value & 0.167 \\
\hline Std. & $4.56 \times 10^{-3}$ & $2.07 \times 10^{-3}$ & & & & \\
$t$ value & 3.223 & 2.926 & & & & \\
$p$ value & $0.015 *$ & $0.022^{*}$ & & & & \\
\hline
\end{tabular}

Note: * Significant at $95 \%$ confidence level. United Nations Scientific Committee on Effects of Atomic Radiation (UNSCAER) $<0.12 \mathrm{mSv} /$ year. World Health Organization $(\mathrm{WHO})<0.01 \mathrm{mSv} /$ year. International Commission on Radiological Protection (ICRP) $<1.0 \mathrm{mSv} /$ year. Polish Ministry of Health $<0.01 \mathrm{mSv} /$ year.

A few studies have predicted chronic human health risk of Po-210 ingestion via drinking water $[9,10,42,71,77]$. Although Zaga et al. [77] estimated Po-210 inhalation and lung cancer, however, there is no significant association study between ingestion of Po-210 via drinking water and types of cancer in human. Luckily, Scott [78] has estimated acute risk of Po-210 ingestion through experimenting on the animal. Scott [78] concluded that: (1) ingestion (or inhalation) of a few tenths of a milligram of Po-210 will likely be fatal to all exposed persons; (2) Lethal intakes are expected to involve fatal damage to the bone marrow which is likely to be compounded by damage caused by higher doses to other organs including the kidneys and liver; (3) Lethal intakes are expected to cause severe damage to the kidney, spleen, stomach, small and large intestines, lymph nodes, skin, and testes (males) in addition to the fatal damage to bone marrow; (4) The time distribution of deaths is expected to depend on the level of radioactivity ingested or inhaled.

Therefore, natural radioactivity ingestion is one of the main causes of human radiation exposure (i.e., global average is $2.4 \mathrm{mSv} /$ year) and it should not exceed $0.1 \mathrm{mSv} /$ year for drinking water according to the European Union Drinking Water Directives (DWD) 98/83/EC [79]. The naturally existing radionuclides in the U-238, Th-232 series, and K-40 are present everywhere in the Earth's crust. Ra-226, U-238 decay series progeny, and K-40 receive more attention due to their high solubility and mobility [80]. In fact, the radioactivity of radionuclides such as U-238, Th-232, and K-40 is very common in water, soil, and rocks [17]. Hence, it presents a serious threat of radiation to the population if ingested [23]. However, the amount of radioactivity of radionuclides in the surface water varies among different places in the world because of territorial and atmospheric sources [81] as 
well as man-made activities [16]. The proportion of natural and artificial radioactivity rates on earth is $85 \%: 15 \%$ [69], whereas in Malaysia the proportion is $80 \%: 20 \%$ [16].

\section{Conclusions}

Po-210 activity in the water supply chain of Langat Basin, Malaysia was within the drinking water quality standard of the Ministry of Health Malaysia and World Health Organization. However, Po-210 activity in the range of $0.63 \pm 0.29$ to $14.98 \pm 1.18 \mathrm{mBq} / \mathrm{L}$ in the Langat River is higher than many countries around the world. The Langat River drains through the granite zone, an extension of the granite batholith series of Peninsular Thailand underneath the basin. Therefore, terrestrial sources are the main contributors of primordial radionuclides, such as U-238 and its progeny Po-210 along with the atmospheric and anthropogenic sources to elevate Po-210 activity in the Langat River. Moreover, the less efficiency i.e., an average $59 \%$ of conventional water treatment method to remove Po-210 entirely from the treated water might be the reason of higher annual effective dose of Po-210 ingestion via drinking water i.e., via tap water $7.41 \times 10^{-3} \mathrm{mSv} /$ year than many countries around the world, even though the limit is safe and the carcinogenic risk is acceptable for human beings. Previous studies have already reported Po-210 is 250,000 times more toxic than hydrogen cyanide, hence it can be carcinogenic to humans if ingested via drinking water for a long time. Moreover, the treated water might become contaminated in the long pipelines in between treatment plants and households. Therefore, a two-layer water filtration system (i.e., effective filtration system at the plants as well as at the household level) should be introduced in the basin to obtain the status of a developed nation by 2020 as well as to achieve the SDG target 6.1 of getting safe drinking water supply well before 2030 .

Author Contributions: M.F.A. has solely prepared the manuscript under the guidance of the co-authors. The co-authors have edited the manuscript several times before submission for the journal publication. First, L.A. and C.A.R.M. conceived and designed the experiments; M.F.A. performed the experiments; M.F.A., C.A.R.M. and M.B.M. analyzed the data; Second, C.A.R.M., M.B.M. and G.C.T. contributed reagents/materials/analysis tools; and M.F.A. wrote the paper.

Funding: The study is supported by the grant: GUP-2017-069 and GUP-2015-029 of the Universiti Kebangsaan Malaysia.

Acknowledgments: The authors are grateful to the Department of Environment Malaysia, Department of Irrigation and Drainage Malaysia, and Malaysian Meteorological Department for the provided data and Information. The authors are also grateful to the Laboratory of Chemical Oceanography, Faculty of Science \& Technology, Universiti Kebangsaan Malaysia for the analysis of water samples as well as to the water treatment plant authorities i.e., Puncak Niaga (M) Sdn. Bhd. and Konsortium Air Selangor Sdn. Bhd. to allow to collect water samples from the outlets of their plants. The authors are also thankful to the Institute of Climate Change, UKM to prepare the study area map through ArcGIS.

Conflicts of Interest: The authors declare no conflict of interest.

\section{References}

1. Yii Mei-Wo, P.; Assyikeen, M.J.N.; Ahmad, Z. Radiation Hazard from Natural Radioactivity in the Sediment of the East Coast Peninsular Malaysia Exclusive Economic Zone (EEZ). Malays. J. Anal. Sci. 2011, 15, $202-212$.

2. Sanusi, M.S.M.; Ramli, A.T.; Wagiran, H.; Lee, M.H.; Heryanshah, A.; Said, M.N. Investigation of geological and soil influence on natural gamma radiation exposure and assessment of radiation hazards in Western Region, Peninsular Malaysia. Environ. Earth Sci. 2016. [CrossRef]

3. Sanusi, M.S.M.; Ramli, A.T.; Gabdo, H.T.; Garba, N.N.; Heryanshah, A.; Wagiran, H.; Said, M.N. Isodose mapping of terrestrial gamma radiation dose rate of Selangor state, Kuala Lumpur and Putrajaya, Malaysia. J. Environ. Radioact. 2014. [CrossRef] [PubMed]

4. Adnan, M.; Siti, N.S.B.; Yusoff, S.; Chua, Y.P. Soil chemistry and pollution study of a closed landfill site at Ampar Tenang, Selangor, Malaysia. Waste Manag. Res. 2013. [CrossRef]

5. Alam, L.; Mohamed, C.A.R. Polonium. Radionuclides in the Environment; Atwood, D.A., Ed.; John Wiley \& Sons Ltd.: Chichester, UK, 2010; pp. 149-154. 
6. Jobbágy, V.; Kávási, N.; Somlai, J.; Máté, B.; Kovács, T. Radiochemical characterization of spring waters in Balaton Upland, Hungary, estimation of radiation dose to members of public. Microchem. J. 2010, 94, 159-165. [CrossRef]

7. Kurttio, P.; Salonen, L.; Ilus, T.; Pekkanen, J.; Pukkala, E. Auvinen, A. Well water radioactivity and risk of cancers of the urinary organs. Environ. Res. 2006, 102, 333-338. [CrossRef] [PubMed]

8. Benedik, L.; Vasile, M.; Spasova, Y.; Wätjen, U. Sequential determination of 210Po and uranium radioisotopes in drinking water by alpha-particle spectrometry. Appl. Radiat. Isot. 2009, 67, 770-775. [CrossRef] [PubMed]

9. Jia, G.; Torri, G.; Magro, L. Concentrations of 238U, 234U, 235U, 232Th, 230Th, 228Th, 226Ra, 228Ra, 224Ra, $210 \mathrm{Po}, 210 \mathrm{~Pb}$ and $212 \mathrm{~Pb}$ in drinking water in Italy: Reconciling safety standards based on measurements of gross $\alpha$ and $\beta$. J. Environ. Radioact. 2009, 100, 941-949. [CrossRef] [PubMed]

10. Seiler, R. 210Po in drinking water, its potential health effects, and inadequacy of the gross alpha activity MCL. Sci. Total Environ. 2016, 568, 1010-1017. [CrossRef] [PubMed]

11. Vasile, M.; Loots, H.; Jacobs, K.; Verheyen, L.; Sneyers, L.; Verrezen, F.; Bruggeman, M. Determination of $210 \mathrm{~Pb}, 210 \mathrm{Po}, 226 \mathrm{Ra}, 228 \mathrm{Ra}$ and uranium isotopes in drinking water in order to comply with the requirements of the EU 'Drinking Water Directive'. Appl. Radiat. Isot. 2016, 109, 465-469. [CrossRef] [PubMed]

12. Maguire, H.; Fraser, G.; Croft, J.; Bailey, M.; Tattersall, P.; Morrey, M.; Walsh, B. Assessing public health risk in the London polonium-210 incident, 2006. Public Health 2010, 124, 313-318. [CrossRef] [PubMed]

13. Walsh, M.; Wallner, G.; Jennings, P. Radioactivity in drinking water supplies in Western Australia. J. Environ. Radioact. 2014, 130, 56-62. [CrossRef] [PubMed]

14. Musa, S. Radioactive Level in Malaysia Still Safe and Low. 2011. UKM News Portal. Available online: http:/ / www.ukm.my/news/arkib/index.php/en/extras/689-radioactive-level-in-malaysia-stillsafe-and-low.html (accessed on 5 August 2018).

15. Almayahi, B.A.; Tajuddin, A.A.; Jaafar, M.S. Measurements of natural radionuclides in human teeth and animal bones as markers of radiation exposure from soil in the Northern Malaysian Peninsula. Radiat. Phys. Chem. 2014, 97, 56-67. [CrossRef]

16. Ahmad, N.; Jaafar, M.S.; Bakhash, M.; Rahim, M. An overview on measurements of natural radioactivity in Malaysia. J. Radiat. Res. Appl. Sci. 2015, 8, 136-141. [CrossRef]

17. Almayahi, B.; Tajuddin, A.; Jaafar, M. Radiation hazard indices of soil and water samples in Northern Malaysian Peninsula. Appl. Radiat. Isot. 2012, 70, 2652-2660. [CrossRef] [PubMed]

18. Tawalbeh, A.A.; Samat, S.B.; Yasir, M.S. Radionuclides level and its radiation hazard index in some drinks consumed in the central zone of Malaysia. Sains Malays. 2013, 42, 319-323.

19. Ahmed, M.F.; Alam, L.; Ta, G.C.; Mohamed, C.A.R.; Mokhtar, M. A Preliminary Study on the Concentration of Po-210 in the Tap Water. In Proceedings of the 3rd International Conference Limit to Growth and Sustainability: Contemporary Issues and Perspectives, Kedah, Malaysia, 5-7 December 2015.

20. Yap, C.K.; Ismail, A.; Tan, S.G.; Omar, H. Concentrations of $\mathrm{Cu}$ and $\mathrm{Pb}$ in the offshore and intertidal sediments of the west coast of Peninsular Malaysia. Environ. Int. 2002. [CrossRef]

21. Ta, G.C.; Meng, C.K.; Mokhtar, M.; Ern, L.K.; Alam, L.; Sultan, M.M.A.; Ali, N.L. Enhancing the regulatory framework for upstream chemicals management in Malaysia: Some proposals from an academic perspective. J. Chem. Health Saf. 2016, 23, 12-18. [CrossRef]

22. Alina, M.; Azrina, A.; Yunus, M.A.S.; Zakiuddin, M.S.; Effendi, M.F.H.; Muhammad, R.R. Heavy metals (mercury, arsenic, cadmium, plumbum) in selected marine fish and shellfish along the straits of Malacca. Int. Food Res. J. 2012, 19, 135-140.

23. Hamzah, Z.; Rosli, T.N.T.M.; Saat, A.; Wood, A.K. An assessment of natural radionuclides in water of Langat River estuary, Selangor. AIP Conf. Proc. 2014, 1584, 228. [CrossRef]

24. Hamzah, Z.; Rahman, S.A.; Saat, A.; Agos, S.S.; Ahmad, Z. Measurement of 226 Ra in river water using liquid scintillation counting technique. J. Nuclear Relat. Technol. 2010, 7, 12-23.

25. Bahari, I.; Mohsen, N.; Abdullah, P. Radioactivity and radiological risk associated with effluent sediment containing technologically enhanced naturally occurring radioactive materials in amang (tin tailings) processing industry. J. Environ. Radioact. 2007, 95, 161-170. [CrossRef] [PubMed]

26. Department of Environment (DOE). Malaysia Environmental Quality Report 2013; Department of Environment: Putrajaya, Malaysia, 2013. 
27. Juahir, H.H. Water Quality Data Analysis and Modeling of the Langat River Basin. Ph.D. Thesis, University of Malaya, Kuala Lumpur, Malaysia, 2009. Available online: http:/ / repository.um.edu.my/1223/5/Chapter\% 203\%20Revised.pdf (accessed on 07 February 2015).

28. Ashraf, M.A.; Maah, M.J.; Yusoff, I.; Wajid, A.; Mahmood, K. Sand mining effects, causes and concerns: A case study from Bestari Jaya, Selangor, Peninsular Malaysia. Sci. Res. Essays 2011. [CrossRef]

29. Memarian, H.; Balasundram, S.K.; Talib, J.B.; Sood, A.M.; Abbaspour, K.C. Trend analysis of water discharge and sediment load during the past three decades of development in the Langat basin, Malaysia. Hydrol. Sci. J. 2012. [CrossRef]

30. Lin, T.I. Regulatory Control of Milling of Minerals Containing Naturally Occurring Radioactive Materials (NORM) in Malaysia. At. Energy Licens. Board, Malaysia. 2015. Available online: https:/ / www.iaea.org/OurWork/ST/NE/NEFW/Technical-Areas/NFC/documents/uranium/trdarwin-2012/Presentations /46.Teng(Malaysia)_-_Regulatory_control_of_NORM_in_Malaysia.pdf (accessed on 1 February 2018).

31. JPN. Atomic Energy Licensing (Radioactive Waste Management) Regulations 2011. Jabatan Peguam Negera/Attorney General's Chambers of Malaysia. Federal Government Gazette, Part VIII, 13 (1b). 16 August 2011. Available online: http:/ / www.aelb.gov.my/malay/dokumen/perundangan/P.U.(A)274.pdf (accessed on 7 August 2018).

32. MOH. Drinking Water Quality Standard. Ministry of Health: Malaysia, 2010. Available online: http: / / kmam.moh.gov.my / public-user / drinking-water-quality-standard.html (accessed on 28 February 2018).

33. Ahmed, M.F.; Lubna, A.; Choo, T.G.; Rahim, M.C.; Mazlin, M. A review on the chemical pollution of Langat River, Malaysia. Asian J. Water Environ. Pollut. 2016, 13, 9-15. [CrossRef]

34. Lim, W.Y.; Aris, A.Z.; Ismail, T.H.T.; Zakaria, M.P. Elemental hydrochemistry assessment on its variation and quality status in Langat River, Western Peninsular Malaysia. Environ. Earth Sci. 2013. [CrossRef]

35. Mohamed, C.A.R.; Ahmad, Z.; Mon, G.C. Aktiviti 226Ra dalam sistem aliran sungai Lembangan Langat, Selangor. Malays. J. Anal. Sci. 2006, 10, 295-302.

36. Yussuf, N.M.; Hossain, I.; Wagiran, H. Natural radioactivity in drinking and mineral water in Johor Bahru (Malaysia). Sci. Res. Essays 2012, 7, 1070-1075. [CrossRef]

37. Amin, Y.B.M.; Jemangin, M.H.; Mahat, R.H. Concentration of Ra-226 in Malaysian Drinking and Bottled Mineral Water. AIP Conf. Proc. 2010, 1250. [CrossRef]

38. Mohamed, C.A.R.; Siang, T.C. Seasonal variation of Po 210 in different salinity: Case of Kuala Selangor river, west coast of peninsular Malaysia. (Special section: Ocean pollution). Coast. Mar. Sci. 2010, 34, 186-194.

39. International Atomic Energy Agency (IAEA). A Procedure for the Determination of Po-210 in Water Samples by Alpha Spectrometry Vienna; International Atomic Energy Agency: Vienna, Austria, 2009.

40. Saili, N.F.B.B. Aktiviti Polonium-210 (210Po) dan Plumbum-210 (210Pb) Dalam turus air di Sungai Mersing, Johor. Master's Thesis, Faculty of Science \& Technology, Universiti Kebangsaan Malaysia, Bangi Selangor, Malaysia, 2012.

41. World Health Organization (WHO). Guidelines for Drinking-Water Quality: Fourth Edition Incorporating the First Addendum; World Health Organization: Geneva, Switzerland, 2017; Available online: http: / apps.who. int/iris/bitstream/10665/254637/1/9789241549950-eng.pdf?ua=1 (accessed on 29 May 2017).

42. Jia, G.; Torri, G. Estimation of radiation doses to members of the public in Italy from intakes of some important naturally occurring radionuclides (238U, 234U, 235U, 226Ra, 228Ra, 224Ra and 210Po) in drinking water. Appl. Radiat. Isot. 2007, 65, 849-857. [CrossRef] [PubMed]

43. Department of Statistics (DOS). Population Distribution by Local Authority Areas and Mukims 2010; Department of Statistics: Putrajaya, Malaysia, 2013. Available online: http:/ / newss.statistics.gov.my/newss-portalx/ep/ epProductFreeDownloadSearch.seam (accessed on 25 November 2015).

44. Yamane, T. Statistics: An Introductory Analysis, 2nd ed.; Harper and Row: New York, NY, USA, 1967.

45. Alam, M.M. Linkages between Climatic Changes and Food Security among the Poor and Low-Income Households in the East Coast Economic Region (ECER), Malaysia. Ph.D. Thesis, Universiti Kebangsaan Malaysia, Bangi Selangor, Malaysia, 2014.

46. Poon, W.C.; Herath, G.; Sarker, A.; Masuda, T.; Kada, R. River and fish pollution in Malaysia: A green ergonomics perspective. Appl. Ergon. 2016, 57, 80-93. [CrossRef] [PubMed] 
47. Juahir, H.; Zain, S.M.; Yusoff, M.K.; Hanidza, T.T.; Armi, A.M.; Toriman, M.E.; Mokhtar, M. Spatial water quality assessment of Langat River Basin (Malaysia) using environmetric techniques. Environ. Monit. Assess. 2011, 173, 625-641. [CrossRef] [PubMed]

48. Aris, A.Z.; Lim, W.Y.; Looi, L.J. Natural and Anthropogenic Determinants of Freshwater Ecosystem Deterioration: An environmental Forensic Study of the Langat River Basin, Malaysia. In Environmental Management of River Basin Ecosystems; Ramkumar, M., Ed.; Springer: Basel, Switzerland, 2015; pp. 455-476.

49. Ehmann, W.D.; Vance, D.E. Radiochemistry and Nuclear Methods of Analysis; John Wiley \& Sons, Inc.: New York, NY, USA, 1991; p. 479. ISBN 0-471-60076-8 (c).

50. Shaheed, K.; Somasundaram, S.S.N.; Hameed, P.S.; Iyengar, M.A.R. A study of polonium-210 distribution aspects in the riverine ecosystem of Kaveri, Tiruchirappalli, India. Environ. Pollut. 1997, 95, 371-377. [CrossRef]

51. Alam, L.; Mokhtar, M.B.; Alam, M.; Bari, M.; Kathijotes, N.; Ta, G.C.; Ern, L.K. Assessment of environmental and human health risk for contamination of heavy metal in tilapia fish collected from Langat Basin, Malaysia. Asian J. Water Environ. Pollut. 2015, 12, 21-30.

52. United States Environmental Protection Agency (USEPA). Radionuclides in Drinking Water: A Small Entity Compliance Guide; United States Environmental Protection Agency: Washington, DC, USA, 2002. Available online: https:/ / www.epa.gov / sites/production/files/2015-06/documents/compliance-radionuclidesindw. pdf (accessed on 12 August 2017).

53. Mokhtar, M.B.; Toriman, M.E.H.; Hossain, A.A. Social learning in facing challenges of sustainable development: A case of Langat River Basin, Malaysia. Res. J. Appl. Sci. 2010, 5, 434-443.

54. Mokhtar, M.B.; Toriman, M.E.H.; Hossain, M.; Abraham, A.; Tan, K.W. Institutional challenges for integrated river basin management in Langat River Basin, Malaysia. Water Environ. J. 2011, 25, 495-503. [CrossRef]

55. Seiler, R.L. 210Po in Nevada groundwater and its relation to gross alpha radioactivity. Groundwater 2011, 49, 160-171. [CrossRef] [PubMed]

56. Theng, T.L.; Mohamed, C.A.R. Activities of 210Po and 210Pb in the water column at Kuala Selangor, Malaysia. J. Environ. Radioact. 2005. [CrossRef] [PubMed]

57. Yunus, S.M.; Hamzah, Z.; Wood, A.K.H.; Saat, A. Natural Radionuclides and heavy Metals Pollution in Seawater at Kuala Langat Coastal Area. Malays. J. Anal. Sci. 2015, 19, 766-774.

58. Lim, W.Y.; Aris, A.Z.; Zakaria, M.P. Spatial Variability of Metals in Surface Water and Sediment in the Langat River and Geochemical Factors That Influence Their Water-Sediment Interactions. Sci. World J. 2012. [CrossRef] [PubMed]

59. Sabuti, A.A.; Mohamed, C.A.R. High 210Po Activity Concentration in the Surface Water of Malaysian Seas Driven by the Dry Season of the Southwest Monsoon (June-August 2009). Estuaries Coasts 2015, 38, $482-493$. [CrossRef]

60. Yusoff, A.H.; Mohamed, C.A.R. Mini Review Uranium-Thorium Decay Series in the Marine Environment of the Southern South China Sea. J. Geol. Geophys. 2016, 5, 1-9. [CrossRef]

61. Vasukevich, T.A.; Nitievskaya, L.S. Application of deactivating properties of some sorbents in aquaculture feed production. Radiats. Biol. Radioecol. 2014, 54, 613-620. [PubMed]

62. Strumińska-Parulska, D.I.; Skwarzec, B.; Tuszkowska, A.; Jahnz-Bielawska, A.; Boryło, A. Polonium (210Po), uranium (238U) and plutonium $(239+240 \mathrm{Pu})$ in the biggest Polish rivers. J. Radioanal. Nucl. Chem. 2010. [CrossRef]

63. Persson, B.R.R.; Holm, E. Polonium-210 and lead-210 in the terrestrial environment: A historical review. J. Environ. Radioact. 2011. [CrossRef] [PubMed]

64. Leong, K.H.; Tan, L.B.; Mustafa, A.M. Contamination levels of selected organochlorine and organophosphate pesticides in the Selangor River, Malaysia between 2002 and 2003. Chemosphere 2007, 66, 1153-1159. [CrossRef] [PubMed]

65. Santhi, V.A.; Sakai, N.; Ahmad, E.D.; Mustafa, A.M. Occurrence of bisphenol A in surface water, drinking water and plasma from Malaysia with exposure assessment from consumption of drinking water. Sci. Total Environ. 2012, 427, 332-338. [CrossRef] [PubMed]

66. Alsalahi, M.A.; Latif, M.T.; Ali, M.M.; Magam, S.M.; Wahid, N.B.A. Distribution of surfactants along the estuarine area of Selangor River, Malaysia. Mar. Pollut. Bull. 2014, 80, 344-350. [CrossRef] [PubMed] 
67. Ahmed, M.F.; Alam, L.; Ta, G.C.; Mohamed, C.A.R.; Mokhtar, M. A Preliminary Study on the Concentration of Po-210 in the Tap Water. In In-House Seminar of the Chemical Oceanography Laboratory; Chemical Oceanography Laboratory, School of Environmental Science and Natural Resources, Faculty of Science and Technology, Universiti Kebangsaan Malaysia: Kuala Selangor, Malaysia, 2016; Volume 1, pp. 34-38, ISBN 978-967-0829-22-7.

68. Hong, G.H.; Park, S.K.; Baskaran, M.; Kim, S.H.; Chung, C.S.; Lee, S.H. Lead-210 and polonium-210 in the winter well-mixed turbid waters in the mouth of the Yellow Sea. Cont. Shelf Res. 1999. [CrossRef]

69. Carvalho, F.P. Distribution, cycling and mean residence time of $226 \mathrm{Ra}, 210 \mathrm{~Pb}$ and $210 \mathrm{Po}$ in the Tagus estuary. Stud. Environ. Sci. 1997. [CrossRef]

70. Desideri, D.; Meli, M.A.; Feduzi, L.; Roselli, C.; Rongoni, A.; Saetta, D. 238U, 234U, 226Ra, 210Po concentrations of bottled mineral waters in Italy and their dose contribution. J. Environ. Radioact. 2007, 94, 86-97. [CrossRef] [PubMed]

71. Skwarzec, B.; Strumińska, D.I.; Borylo, A. The radionuclides 234 U, 238 U and 210 Po in drinking water in Gdańsk agglomeration (Poland). J. Radioanal. Nucl. Chem. 2001, 250, 315-318. [CrossRef]

72. Kannan, V.; Iyengar, M.A.R.; Ramesh, R. Dose estimates to the public from 210Po ingestion via dietary sources at Kalpakkam (India). Appl. Radiat. Isot. 2001, 54, 663-674. [CrossRef]

73. Outola, I.; Nour, S.; Kurosaki, H.; Inn, K.; LaRosa, J. Investigation of radioactivity in selected drinking water samples from Maryland. J. Radioanal. Nucl. Chem. 2008, 277, 155-159. [CrossRef]

74. Irlweck, K. Determination of $210 \mathrm{~Pb}, 210 \mathrm{Bi}$ and $210 \mathrm{Po}$ in natural drinking water. J. Radioanal. Nucl. Chem. 2001, 249, 191-196. [CrossRef]

75. Kozłowska, B.; Walencik, A.; Dorda, J.; Przylibski, T.A. Uranium, radium and 40K isotopes in bottled mineral waters from Outer Carpathians, Poland. Radiat. Meas. 2007, 42, 1380-1386. [CrossRef]

76. World Health Organization (WHO). Polonium-210: Basic Facts and Questions; World Health Organization: Grneva, Switzerland, 2018; Available online: http://www.who.int/ionizing_radiation/pub_meet/ polonium210/en/ (accessed on 10 March 2018).

77. Zaga, V.; Lygidakis, C.; Chaouachi, K.; Gattavecchia, E. Polonium and lung cancer. J. Oncol. 2011. [CrossRef] [PubMed]

78. Scott, B.R. Health risk evaluations for ingestion exposure of humans to polonium-210. Dose-Response 2007, 5, 94-122. [CrossRef] [PubMed]

79. Munter, R. Technology for the removal of radionuclides from natural water and waste management: State of the art Rein Munter. Proc. Est. Acad. Sci. 2013. [CrossRef]

80. Yii, M.W.; Zaharudin, A.; Abdul-Kadir, I. Distribution of naturally occurring radionuclides activity concentration in East Malaysian marine sediment. Appl. Radiat. Isot. 2009. [CrossRef] [PubMed]

81. Ramli, A.T.; Hussein, A.W.M.A.; Wood, A.K. Environmental 238U and 232Th concentration measurements in an area of high level natural background radiation at Palong, Johor, Malaysia. J. Environ. Radioact. 2005. [CrossRef] [PubMed]

(C) 2018 by the authors. Licensee MDPI, Basel, Switzerland. This article is an open access article distributed under the terms and conditions of the Creative Commons Attribution (CC BY) license (http://creativecommons.org/licenses/by/4.0/). 